\title{
Penerapan askep pada pasien an. $R$ dengan bronchopneumonia dalam pemenuhan kebutuhan oksigenasi
}

Aslinda

Prodi DIII Keperawatan Unismuh Makassar

\begin{abstract}
Keywords :
Bronchopneumonia, Nursing care, Oxygenation.
\end{abstract}

\section{Kontak :}

Aslinda

Email : aslindaelly@yahoo.co.id

Prodi DIII Keperawatan, Universitas

Muhammadiyah Makassar

Vol 2 No 1 September 2019

DOI:

https://doi.org/10.31605/jhealt.v2i1

(C)2019J-Healt

ini adalah artikel dengan akses terbuka dibawah licenci CC BY-NC-4.0

https://creativecommons.org/licenses/by-nc/4.0/

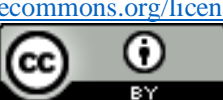

\begin{abstract}
Abstrak
Anak sangat rentang terhadap berbagai penyakit yang bisa disebabkan oleh kuman, virus dan migroorganisme lain. Penyakit yang sering terjadi pada anak yaitu penyakit pada saluran pernafasan. Oksigen merupakan kebutuhan dasar manusia yang paling vital. Oksigen dibutuhkan oleh tubuh untuk menjaga kelangsungan metabolisme sel sehingga dapat mempertahankan hidup dan aktivitas berbagai sel, jaringan atau organ. Salah satu penyakit yang sering terdapat pada anak adalah Bronchopneumonia. Bronchopneumonia adalah radang paruparu yang mengenai satu atau beberapa lobus paru-paru yang ditandai dengan adanya bercak-bercak infiltrate yang disebabkan oleh bakteri, virus, jamur dan benda asing. Menggambarkan Asuhan Keperawatan pada pasien An "R" dengan Bronchopneumonia dalam pemenuhan kebutuhan Oksigenasi. Studi kasus ini menggunakan rancangan analisis deskriptif. Dengan pendekatan proses keperawatan. terhadap pasien anak bronchopneumonia dalam pemenuhan kebutuhan oksigenasi. Data yang dikumpulkan dalam penelitian ini menggunakan format pengkajian, format wawancara dan lembar observasi. Setelah dilakukan tindakan keperawatan selama $3 \times 12$ jam pada pasien An. R dengan masalah oksigenasi telah teratasi. Berdasarkan dari hasil tindakan yang dilakukan pada An. $\mathrm{R}$ dapat disimpulkan bahwa masalah bersihan jalan nafas tidak efektif dapat teratasi dengan baik sesuai hasil yang diharapkan.
\end{abstract}

\section{Abstract}

Children are very vulnerable to various diseases that can be caused by germs, viruses and other migroorganisms. Diseases that often occur in children are diseases of the respiratory tract. Oxygen is the most vital basic human need. Oxygen is needed by the body to maintain the continuity of cell metabolism so that it can maintain life and activity of various cells, tissues or organs. One disease that is often found in children is bronchopneumonia. Bronchopneumonia is inflammation of the lungs that affects one or more lung lobes which is characterized by patches of infiltrate caused by bacteria, viruses, fungi and foreign bodies. Describes Nursing Care in An " $R$ " patients with Bronchopneumonia in meeting Oxygenation needs. This case study uses descriptive analysis design. With the nursing process approach. in bronchopneumonia pediatric patients in fulfilling oxygenation needs. Data collected in this study uses the assessment format, interview format and observation sheet. After taking nursing action for $3 \times 12$ hours in patients An. $R$ with oxygenation problems has been resolved. Based on the results of actions taken on An. $R$ can be concluded that the problem of ineffective airway cleansing can be resolved properly according to the expected results. 


\section{Pendahuluan}

Anak sangat rentang terhadap berbagai macam penyakit yang disebabkan oleh kuman,virus dan mikroorganisme lain. Penyakit yang sering terjadi pada anak yaitu penyakit pada saluran pernafasan. Pada saluran pernafasan manusia memerlukan oksigen yang dihirup setiap detiknya. Oksigen merupakan kebutuhan dasar manusia yang paling vital. Oksigen dibutuhkan oleh tubuh untuk menjaga kelangsungan metabolisme sel sehingga dapat mempertahankan hidup dan aktivitas berbagai sel, jaringan, atau organ (Saputra, 2013).

Salah satu penyakit pada anak dengan gangguan pemenuhan kebutuhan oksigen yaitu Bronchopneumonia. Bronchopneumonia adalah suatu peradangan paru yang biasanya menyerang di bronkiolus terminal. Bronkiolus tersumbat oleh eksudat mokopurulen yang membentuk bercak-bercak konsolidasi di lobuli yang berdekatan, yang disebabkan oleh bakteri, virus dan jamur dan benda asing. Penyakit ini sering bersifat sekunder, menyertai infeksi saluran pernafasan atas,deman infeksi yang spesifik dan penyakit yang melemahkan daya tahan tubuh.( Sudigdiodi,2015).

Bronchopneumonia merupakan masalah kesehatan di dunia karena angka kematiannya sangat tinggi pada anak dan balita. Berdasarkan data Word Healt Organization (WHO) pada tahun 2016 terdapat 6,3 juta atau (15\%) kematian anak-anak di bawah umur 5 tahun, dan sebesar 922.000 atau (15\%) kematian anak disebabkan oleh bronchopneumonia (Kaunang, Runtunuwa \& Wahani,2016).

Penyakit Bronchopneumonia yang masih merupakan masalah kesehatan yang dianggap serius di Indonesia karena urutan ke -2 setelah diare. Angka kejadian Bronchopneumonia disebagian besar wilayah Indonesia cukup tinggi khususnya pada anak dan balita. Berdasarkan hasil dari Riskesdas tahun 2016, angka kejadian pada penderita Bronchopneumonia maupun Pneumoia di
Indonesia, insiden tertinggi pada balita terdapat pada kelompok umur 12-23 Bulan, jumlah kasus Bronchopneumonia di Provinsi Sulawesi Selatan pada tahun 2016 jumlah perkiraan balita penderita Bronchopneumonia sebesar 74.204 orang dan jumlah balita penderita Bronchopneumonia yang ditemukan dan ditangani sebanyak 13,147 atau $17,72 \%$ (Dinkes Prov.Sul-Sel 2016).

Bronchopneumonia dapat menyebabkan terjadinya penumpukan eksudat dan apabila tidak dikeluarkan akan menyebabkan masalah gangguan saluran pencernaan dan mengganggu saluran pernafasan yang di sebabkan oleh bakteri, virus, jamur, ataupun benda asing, yang ditandai dengan gejala panas yang tinggi, gelisah, dipsnea, napas cepat dan dangkal, muntah, diare, batuk kering dan produktif yang mengganggu kebutuhan oksigenasi (Hidayat,2012).

Menurut Nugroho (2011) batuk efektif adalah salah satu upaya untuk mengeluarkan sekret untuk menjaga paru-paru agar tetap bersih selain dengan memberikan tindakan Nebulizer.Tindakan ini bertujuan untuk membersihkan sekresi yang menyumbat pada jalan nafas, tindakan juga ini bertujuan untuk meningkatkan ekspansi paru, mobilisasi paru, dan mencengah efek samping dari banyakya sekret yang menumpuk seperti atelectasis,dan deman.

Dari uraian diatas penulis tertarik untuk melakukan studi kasus tentang penyakit Bronchopneumonia Pada An. R Dengan Kebutuhan Oksigenasi: bersihan jalan nafas tidak efektif dengan harapan bahwa setelah dilakukannya studi kasus maka angka kejadian kasus Bronchopneumonia dengan gangguan kebutuhan oksigenasi dapat teratasi khususnya yang terjadi pada anak di RS TK II Pelamonia.

\section{METODE}

Penelitian ini dilakukan di RS TK II Pelamonia pada tanggal 30 Mei s/d 01 Juni 
2018, dengan desain penelitian yang digunakan adalah analisis deskriptif dengan pendekatan studi kasus, yaitu penelitian yang berfokus pada suatu kasus tertentu untuk diamati dan dianalisis secara cermat sampai tuntas.

Populasi dalam studi kasus ini adalah semua pasien Anak dengan masalah Bronchopneumonia. Sampel dalam studi kasus ini sesuai dengan kriteris inklusi yaitu pasien anak Bronchopneumonia yang mengalami gangguan oksigenasi yang dirawat di ruang perawatan anak.

Alat pengumpulan data dalam studi kasus ini menggunakan format pengkajian, format wawancara dan lembar observasi. Analisa data yang dilakukan pada studi kasus ini adalah dengan mendeskripsikan informasi yang telah tersusun dan melakukan penarikan kesimpulan serta pengambilan tindakan. Data yang telah tersusun kemudian disajikan dalam bentuk narasi yang mudah dipahami.

Pengambilan data dan pemberian asuhan keperawatan pada studi kasus ini dilaksanakan setelah mendapatkan imformed consent dari keluarga pasien dan tetap memperhatikan etika penelitian yang meliputi Anonimity (tanpa nama), kerahasiaan (confidentiality), Respect for justice and inclunsinevenes, dan balancing harms and benefits.

\section{HASIL PENELITIAN}

Berdasarkan hasil pengkajian pada klien didapatkan data, pasien berumur 1 Tahun 4 bulan dengan keluhan utama adalah batuk berlendir dan suara nafas ronchi, ibu klien mengatakan anaknya sering batuk berlendir, dan usaha ibu klien saat menangani batuk berlendir anaknya adalah memberikan air hangat. Menurut ibu klien penyebab dari batuk berlendir adalah apabila klien sudah minum minuman yang mengandung pemanis buatan. Dan batuk klien sangat menganggu pada saat malam hari. Hasil pemeriksaan fisik didapatkan keadaan umum An.R adalah lemah, konjungtiva pucat, pengukuran tanda- tanda vital suhu $36,5^{\circ} \mathrm{C}$, frekuensi nadi 120 kali permenit dan frekuensi pernafasan $28 \mathrm{kali}$ permenit. Berat Badan 7,5 kg, dan Tinggi Badan $73 \mathrm{~cm}$, batuk berlendir, bunyi nafas ronchi, pada tangan kanan terpasang IVFD Dextrose., Dan hasil pemeriksaan foto Thorax AP pada tanggal 29 Mei 2018 yaitu: tampak bercak infiltrate pada kedua paru, cor : bentuk, letak dan ukuran dalam batas normal, kedua sinus dalam batas normal, tulangtulang intak, kesan Bronchopneumonia. dari data yang diperoleh di dapatkan masalah keperawatan dengan diagnosa bersihan jalan nafas tidak efektif berhubungan dengan produksi sekret yang berlebihan. Perencanaan sesuai masalah keperawatan pada klien yaitu kaji frekuensi atau pantau pernafasan yang rasionalnya mengetahui frekuensi pernafasan klien sebagai indikasi dasar gangguan pernafasan. Auskultasi bunyi nafas tambahan (ronchi, wheezing) yang rasionalnya bunyi nafas tambahan yang menandakan adanya gangguan pernafasan. Berikan posisi yang nyaman dengan rasional posisi yang memungkinkan ekspansi paru lebih maksimal. Berikan air hangat dibanding air dingin dengan rasional cairan, khususnya yang hangat dapat memobilisasi lendir serta Kolaborasi dengan dokter dalam pengisapan lendir sesuai indikasi (suction atau nebulizer) untuk mengeluarkan lendir lendir secara mekanik dan mencegah obstruksi jalan nafas.

Tindakan keperawatan dilaksanakan selama 3 X 24 jam berdasarkan dengan intervensi keperawatan yang telah disusun yaitu Mengkaji frekuensi pernafasan klien diperoleh hasil pernafasan klien $30 \mathrm{X} /$ menit. Mengauskultasi bunyi nafas tambahan diperoleh hasil terdengar bunyi ronchi. Memberikan posisi yang nyaman dengan hasil klien nyaman dalam gendongan ibunya. Memberikan air hangat dengan hasil klien minum air hangat. Kolaborasi dengan dokter dalam pengisapan lendir sesuai indikasi dengan hasil klien diberikan nebulizer dan sekret keluar saat selesai di nebulizer.

Setelah dilakukan tindakan keperawatan, hasil evaluasi dari tindakan yang dilakukan dengan metode SOAP, didapatkan pada hari Rabu 
tanggal 30 Mei 2018 Pukul 13.00 WITA dengan masalah keperawatan bersihan jalan nafas tidak efektif berhubungan dengan produksi sekret yang berlebihan telah dievaluasi dan didapatkan hasil dari data subjektif ibu klien mengatakan anaknya masih batuk berlendir. Data objektif didapatkan klien nampak batuk berlendir, bunyi nafas ronchi, terdapat sekret keluar saat selesai dinebulizer. Assesment masalah belum teratasi. Planning lanjutkan intervensi yaitu berikan posisi yang nyaman, berikan air hangat, kolaborasi dengan dokter dalam pemberian nebulizer. Evaluasi dari tindakan pada hari kamis tanggal 31 Mei 2018 dengan masalah keperawatan bersihan jalan nafas tidak efektif berhubungan dengan produksi sekret yang berlebihan telah dievaluasi dan didapatkan hasil data subjektif ibu klien mengatakan anaknya masih batuk berlendir. Data objektif suara nafas ronchi, terdapat lendir keluar setelah nebulizer, pernafasan 28 $\mathrm{X} / \mathrm{menit}$. Assesment masalah belum teratasi. Planning lanjutkan intervensi yaitu kaji frekuensi atau pantau pernafasan klien, auskultasi bunyi nafas tambahan, berikan posisi yang nyaman, berikan air hangat dan kolaborasi dengan dokter dalam pengisapan lendir sesuai indikasai. Evaluasi dari tindakan pada hari Jumat tanggal 01 Juni 2018 pada pukul 15.00 WITA dengan masalah keperawatan bersihan jalan nafas tidak efektif berhubungan dengan produksi sekret yang adekuat telah dievaluasi dan didapatkan hasil data subjektif ibu klien mengatakan anaknya sudah tidak batuk berlendir. Data objektif klien nampak tidak batuk berlendir, tidak terdengar bunyi nafas ronchi, tidak terdapat sekret keluar setelah nebullizer, pernapasan $26 \mathrm{X} /$ menit. Assesment masalah teratasi. Planning pertahankan intervensi seperti kaji frekuensi atau pantau pernafasan klien, auskultasi bunyi nafas tambahan seperti ronchi dan wheezing, berikan posisi yang nyaman, berikan air hangat dan kolaborasi dengan dokter dalam pengisapan lendir.

\section{PEMBAHASAN}

Hasil pengkajian pada An"R" didapatkan data batuk berlendir, konjungtiva pucat, bunyi nafas ronchi. Menurut Riyadh dan Sukarmin 2013 bahwa batuk berlendir disebabkan karena adanya infeksi paru-paru dan peradangan pada bronkus akan mengakibatkan peningkatkan produksi mukosa dan peningkatan gerakan sillia pada bronkus sehingga timbul peningkatan refleks batuk untuk mengeluarkan lendir., Konjungtiva pucat di sebabkan oleh kurangnya suplai darah ke kulit seperti pada keadaan pingsan syok, serta hipoglikemia, menurut penelitian Ilham (2011) kongjuntiva pucat dapat dapat disebabkan oleh darah tidak sampai ke perifer sehingga menyebabkan seorang mengalami konjungtiva anemis., bunyi nafas ronchi disebabkan adanya penumpukan sekret kental dan peningkatan produksi sputum yang mengakibatkan sumbatan pada saluran pernafasan Menurut penelitian Kauanang, Runtunuwa, \& Wahani (2016) bunyi nafas ronchi berasal dari bronki yang lebih besar atau trakea dan mempunyai bunyi yang berpuncak pada pasien yang mengalami penurunan sekresi, Hal ini disebabkan adanya sekret yang menutupi jalan nafas, sehingga saat pasien ekspirasi terdapat suara gaduh sehingga tidak mampu mempertahankan bersihan jalan nafas.

Pada Diagnosa Keperawatan, diangnosa keperawatan yang muncul pada penyakit Bronchopneumonia menurut Saputra (2013) yaitu Ketidakefektifan bersihan jalan nafas, berhubungan dengan: produksi sekret yang berlebihan dan kental dapat disebabkan oleh infeksi, inflamasi, alergi, rokok, dan penyakit jantung atau paru, imobilitas, statis sekret, dan batuk tidak efektif akibat gangguan pada sistem saraf pusat, depresi sistem saraf pusat atau trauma kepala, dan cedera serebrovaskular, efektif sedatif dari obat, pembedahan (beda torak), trauma nyeri, kelelahan, gangguan kognitif, dan persepsi, terpapar udara dingin, tertawa, menangis, alergi, dan merokok, berkurangnya mekanisme pembersihan silia dan respon peradangan. Dan diagnosa ini juga 
didapatkan pada kasus ditandai dengan data yang ditemukan pada kasus, yaitu data subjektif: ibu klien mengatakan klien batuk berlendir. Data Objektif: klien nampak batuk berlendir, bunyi nafas ronchi.

Pada perencanaan penulis menyusun rencana keperawatan sesuai dengan teori dan studi kasus. Rencana keperawatan dengan tujuan setelah dilakukan tindakan keperawatan selama 3x12 jam, bersihan jalan nafas tidak efektif dengan kriteria hasil klien tidak batuk, tidak terdengar bunyi nafas ronchi, tidak ada sekret dapat teratasi.

Perencanaan yang dibuat berdasarkan diagnosa keperawatan Perencanaan sesuai masalah keperawatan pada klien yaitu kaji frekuensi atau pantau pernafasan yang rasionalnya mengetahui frekuensi pernafasan klien sebagai indikasi dasar gangguan pernafasan. Auskultasi bunyi nafas tambahan (ronchi, wheezing) yang rasionalnya bunyi nafas tambahan yang menandakan adanya gangguan pernafasan. Berikan posisi yang nyaman dengan rasional posisi yang memungkinkan ekspansi paru lebih maksimal. Berikan air hangat dibanding air dingin dengan rasional cairan, khususnya yang hangat dapat memobilisasi lendir serta Kolaborasi dengan dokter dalam pengisapan lendir sesuai indikasi (suction atau nebulizer) untuk mengeluarkan lendir lendir secara mekanik dan mencegah obstruksi jalan nafas.

Hasil Implementasi dilakukan berdasarkan intervensi yang telah disusun dari diagnosa yang ditegakkan dalam studi kasus. Semua perencanaaan terlaksana dengan baik tanpa ada kendala karena adanya dukungan dari keluarga dalam mengaplikasikan tindakan tersebut.

Evaluasi adalah tahap akhir dari proses keperawatan yang digunakan sebagai titik acuan terhadap tindakan yang telah dilakukan, apakah masalah tersebut teratasi atau tidak teratasi. Evaluasi yang di lakukan setelah melakukan tindakan dengan masalah bersihan jalan nafas tidak efektif, Merurut
Kozier ( 2011), evaluasi keperawatan pana An. $\mathrm{R}$ dalam masalah kebutuhan oksigenasi secara umum dapat dilihat dari kemampuan anak dalam mempertahankan jalan nafas efektif yang dapat dinilai dari kemampuan bernafas secara normal dan tidak terdapat sumbatan jalan nafas.

Dari diagnosa keperawatan yang ditegakkan penulis pada kasus An. R selama 3 (tiga) hari diruangan Di Rumah Sakit TK II Pelamonia Makassar,setelah melakukan tindakan keperawatan 3x24 jam, evaluasi kasus pada klien An. R teratasi yaitu:Ketidakefektifan bersihan jalan nafas berhubungan dengan produkksi sekret yang berlebihan, Subjektif Ibu klien mengatakan klien sudah tidak batuk berlendir lagi,Objektif Klien nampak tidak batuk lagi, Frekuensi pernafasan 26x/menit, Suhu $36^{\circ} \mathrm{C}$, Tidak terdengar bunyi nafas ronchi, Tidak ada sekret. Assesment: Masalah teratasi, Planning: Pertahankan intervensi.

\section{KESIMPULAN}

Hasil pengkajian pada klien An. R, adalah lemah, konjungtiva pucat, pengukuran tandatanda vital suhu $36,5^{\circ} \mathrm{C}$, frekuensi nadi 120 kali permenit dan frekuensi pernafasan 28 kali permenit. Berat Badan 7,5 kg, dan Tinggi Badan $73 \mathrm{~cm}$, batuk berlendir, bunyi nafas ronchi dengan hasil foto thorax nampak bercak infiltrate pada kedua paru.

Diagnosa keperawatan utama yang ditegakkan oleh penulis pada An. $\mathrm{R}$ adalah Bersihan jalan nafas tidak efektif berhubungan dengan peningkatan produksi sekret. Rencana Asuhan Keperawatan pada An. R dengan Bersihan jalan nafas tidak efektif dengan tujuan setelah dilakukan tindakan keperawatan bersihan jalan nafas teratasi teratasi dengan kriteria hasil bersihan jalan nafas kembali efektif, klien tidak batuk berlendir, tidak terdengar bunyi nafas ronchi, tidak ada sekret.

Implementasi yang dilakukan berdasarkan diagnose keperawatan pada An"R" dengan masalah ketidakefektifan bersihan jalan nafas yaitu Mengkaji frekuensi pernafasan klien, 
Mengauskultasi bunyi nafas tambahan, Memberikan posisi yang nyaman, Memberikan air hangat, serta Kolaborasi dengan dokter dalam pemberian nebulizer. Evaluasi terhadap keberhasilan tindakan yang dilakukan pada An. R dengan hasil evaluasi akhir yaitu jalan nafas efektif.

\section{SARAN}

Di harapkan kepada masyarakat khusus orang tua dapat menambah ilmu pengetahuan tentang penyakit Bronchopneumonia dan lebih memperhatikan gejala dan kondisi anakanak agar tidak terjadi penyakit Bronchopneumonia dengan ketidakefektifan bersihan jalan nafas.

Di harapkan kepada seluruh pengembangan dan tehnologi keperawatan agar lebih memperdalam ilmu dan tehnologi terapan bidang keperawatan, khususnya dalam bidang keperawatan anak agar lebih memperhatikan bersihan jalan nafas pasien anak bronchopneumonia.

Di harapkan kepada seluruh pengembangan dan tehnologi keperawatan agar semua pasien anak Bronchopneumonia di RS TK II Pelamonia Makassar agar diberikan penyuluhan dan konseling tentang Bronchopneumonia.

Di harapkan agar penulis dapat menambah wawasan dan ilmu pengetahuan serta melakukan penelitian lebih lanjut mengenai penerapan asuhan klien secara optimal mengenai Penerapan Asuhan keperawatan ketidakefektifan bersihan jalan nafas agar pasien mampu memperoleh kebersihan jalan nafas yang efektif.

\section{Ucapan Terima Kasih}

Kepada Bapak dr. H. Mahmud Ghaznawie. Ph. D., Sp.PA (K) selaku dekan Fakultas Kedokteran Dan Ilmu Kesehatan Universitas Muhammadiyah Makassar, Ibunda Ratna Mahmud S.Kep., Ns., M.Kes, selaku Ketua
Program studi Keperawatan, Kepala Ruangan Dahlia RS TK II Pelamonia Makassar beserta seluruh Staff dan semua pihak yang telah memberikan support dan bantuannya yang tidak dapat kami disebutkan satu persatu.

\section{Referensi}

Hidayat,A,A.(2012).Buku Pengantar Ilmu KeperawatanAnak.Jakarta:Salemba Medika

Heriana, P.(2014).Buku Ajar Kebutuhan Dasar Manusia . Tanggeran Selatan BiNAPURA AKSARA.

Kozier,B.ERB.(2011) Buku Ajar Fundamental Keperawatan:Konsep,Proses \& Praktik,Ed. 7.Vol.1.

Kaunang, C.T,Runtunuwu, A,L,\& Wahani,A. M. I (2016) Gambaran karakteristik pneumonia pada anak yang dirawat diruang perawatan intensif anak RSUP PROF.DR. D. Kandou Manado periode 2014-2016. Diakkes dari http:ejournal.unimus.ac.id.

Nugroho,Y .A,Kristianti ,E (2011) Batuk efektif dalam pengeluaran batuk pada pasien dengan Ketidakefektifan Bersihan Jalan Nafas di instalasi Rehabilitasi medic Rumah Sakit Baptis Kediri.jurnal STIKES RS.Baptis Kediri.Volume 4,No.2. Diakkes dari http:jurnal.unimus.ac.id.

Profil Kesehatan.(2016) Profil Rencana Kesehatan Provinsi Sulawesi Selatan Diakses dari http//www.depkes.go.id

Riyadi, S.,\& Sukarmin (2013). Asuhan Keperawatan Pada Anak. Yogyakarta: Graha Ilmu

Saputra,.L. (2013).Catatan Ringkas Kebutuhan Dasar Manusia. Tanggeran Selatan: Binapura Aksara Publisher. 